\title{
PEMERATAAN DAN PENINGKATAN MUTU PENDIDIKAN MELALUI KOMUNITAS GURU ONLINE
}

\author{
I Made Candiasa, Ni Made Sri Mertasari, Komang Setemen, Gusti Ketut Arya Sunu \\ Universitas Pendidikan Ganesha \\ Singaraja, Indonesia
}

\begin{abstract}
Abstrak
Perluasan akses dan pemerataan mutu merupakan masalah pendidikan yang harus segera dicari solusinya. Banyak upaya sudah dilakukan, namun hasilnya belum optimal karena menghadapi beberapa kendala, seperti perbedaan kondisi geografis, ekonomi masyarakat, dan pendapatan daerah. Salah satu solusi yang telah dikembangkan adalah portal web komunitas guru on-line yang dapat memfasilitasi proses subsidi silang informasi pembelajaran. Media ini sudah diuji oleh pakar dan diujicoba terbatas dengan melibatkan beberapa orang guru, beberapa orang siswa, dan beberapa orang anggota masyarakat umum. Hasil uji pakar menunjukkan bahwa media ini memenuhi syarat cukup untuk diterapkan. Hasil uji coba terbatas menunjukkan bahwa media ini cukup efektif untuk dijadikan media pertukaran informasi antar-guru dan menjadi media belajar yang efektif bagi siswa. Media ini dapat menjadi perpanjangan tangan dari forum seperti musyawarah guru mata pelajaran (MGMP) karena mampu mengkomunikasikan guru-guru lintas kabupaten/kota dan bahkan lintas provinsi. Selain itu, media ini dapat dimanfaatkan sebagai media evaluasi diri bagi sekolah karena dari media tersebut sekolah dapat membandingkan dirinya dengan sekolah lain dalam kualitas pembelajaran Mekanisme seperti di atas diharapkan dapat mendorong pemerataan dan peningkatan mutu pendidikan.
\end{abstract}

Kata-kata kunci: media, komunitas, guru, online

\begin{abstract}
Main problem of our education recently are extending access and enhancing quality of education. Many solutions have been done, but these results were not optimum yet because of geographics condition, social economic condition, and low regional income. Right now, media to facilitate online of teacher community has been implemented and have been tried out by expert. In addition, this media has also tried out for several teachers, students, and other community. It was found that this media can facilitate instructional information exchange among teachers. Therefore, the media built communication link among teacher community across county and also across province. On the other hand, this media give opportunity to students to access instructional information of teachers from others school. Finally, this media can act as self evaluation media for schools or teachers, where teachers or schools can compare their instructional quality with the others schools or teachers. We are hopefully that this work can enhance education quality and widespread educational access.
\end{abstract}

Keywords: media, community, teachers, online

\section{PENDAHULUAN}

Perluasan akses dan peningkatan mutu pendidikan merupakan salah satu tuntutan masyarakat untuk layanan di bidang pendidikan. Indonesia merupakan negara kepulauan dengan kondisi geografis dan kondisi pendapatan daerah maupun penduduk yang bervariasi, sehingga berimplikasi pada variasi capaian pembangunan, termasuk pembangunan pendidikan. Variasi tersebut perlu difasilitasi dengan segera agar terjadi peningkatan sekaligus pemerataan mutu pendidikan. Subsidi silang tenaga ahli, dana, dan fasilitas menjadi salah satu solusi, namun solusi tersebut relatif sulit diimplementasikan. Solusi lain yang lebih berpeluang untuk diimplementasikan adalah penyediaan media yang memungkinkan terjadinya pertukaran dan subsidi silang informasi pembelajaran 
menembus perbedaan geografis dan perbedaan ekonomi. Media yang dapat berfungsi seperti di atas adalah portal web pembelajaran yang dilengkapi fasilitas untuk membentuk komunitas guru on-line. Infrastruktur teknologi informasi dan komunikasi (jaringan internet) sangat mendukung media tersebut.

UNDIKSHA sebagai lembaga pendidikan tenaga kependidikan berkepentingan terhadap media tersebut. Oleh karena itu, sudah selayaknya UNDIKSHA memprakarsai dan terlibat langsung dalam pengembangan media tersebut. Agar hasil yang diperoleh optimal, koordinasi terus dilakukan dengan dinas pendidikan yang bertanggungjawab dalam manajemen guru dan LPMP yang bertanggungjawab terhadap peningkatan mutu guru. Apabila media tersebut sudah selesai dibangun, maka pengelolaan diserahkan kepada dinas pendidikan provinsi dan pengkoordinasiannya dilakukan oleh pihak LPMP. Pihak UNDIKSHA selanjutnya bertindak sebagai konsultan pengembangan dan pemeliharaan sistem. Dengan demikian keberlanjutan sistem dapat terjamin.

Tuntutan mutu pendidikan dari masyarakat dan standarisasi mutu pendidikan yang ditunjukkan dengan adanya ujian nasional memacu sekolah untuk melakukan berbagai upaya untuk meningkatkan mutu layanan pendidikan. Melihat kondisi tersebut, animo guru untuk tergabung ke dalam komunitas guru on-line menjadi tinggi, apalagi bila ditambah dengan adanya dorongan dari para kepala sekolah, komite sekolah, dan dinas pendidikan. Selain itu, kesinambungan portal web komunitas guru on-line akan dapat terpelihara dengan baik melalui koordinasi dengan lembaga-lembaga yang mengelola komunitas pelaksana pendidikan, seperti musyawarah guru mata pelajaran (MGMP) dan kelompok kerja kepala sekolah (K3S). Apabila terjadi koordinasi yang baik di internal MGMP dan di internal K3S serta antara MGMP dan K3S, maka kesinambungan dan perkembangan komunitas guru on-line akan dapat dijamin. Selain itu, dinas pendidikan dapat bekerjasama dengan LPMP menerbitkan regulasi untuk menjamin keterlibatan guru dalam komunitas guru on-line, seperti keterlibatan guru dalam MGMP.

Komunitas belajar on-line adalah kelompok belajar yang didasari oleh komitmen dan kepentingan bersama untuk belajar secara kolaboratif dengan difasilitasi lingkungan belajar maya (Ke \& Hoadley, 2009). Pembelajaran on-line terjadi pada lingkungan maya (virtual) memanfaatkan fasilitas jaringan komputer (internet), sehingga terlepas dari komunikasi tatap muka. Karakteristik komunikasi bermedia komputer seperti bebas konteks, bebas konvensi sosial sangat memacu terjadinya komunikasi yang lebih bermakna, apalagi bagi siswa yang memiliki gangguan komunikasi tatap muka. Sofos \& Kostas (2009) menemukan bahwa proses keterlibatan dalam komunitas on-line secara praktis telah mampu meningkatkan kemampuan guru dalam mengelola web pembelajaran, sehingga memenuhi kriteria web pembelajaran standar. Sebelumnya, Sofos \& Kostas (2009) menemukan sangat sedikit web pembelajaran yang dapat memenuhi kriteria fungsional, edukasional, dan didaktikal. Hal ini terjadi karena guru hanya memahami web sebagai media pembelajaran, sehingga guru belum mengintegrasikan web pada pembelajaran di kelas, melainkan memanfaatkannya secara sporadis. Selain itu, guru lebih menekankan pada isi bahan ajar dan relevansinya dengan program pembelajaran, sehingga kurang memperhatikan aspek lain seperti fleksibilitas penampilan, ergonomi, atau variabilitas modus pembelajaran.

Situs web komunitas guru online memberi peluang kepada siswa untuk dapat mengakses materi dari berbagai situs secara simultan, baik berupa teks, audio, atau video. Siswa dapat berinetraksi dengan 
guru dan siswa dari berbagai cara. Siswa dapat secara mandiri mengatur pembelajarannya dan guru dapat meningkatkan kemampuannya untuk mengelola pembelajaran melalui kolaborasi dengan koleganya. Beberapa siswa berpengalaman mengungkapkan kesulitan belajarnya dan bahkan mengajukan pertanyaan kepada kolega dari sekolah lain yang belum pernah mereka kenal. Jadi siswa memiliki kesempatan untuk mengakses materi dari lingkungan yang lain, bukan hanya dari lingkungan lokal mereka untuk memperluas wawasan. Dengan demikian siswa dapat belajar dengan nyaman serta berkomunikasi dengan lugas dengan siswa lainnya dan dengan guru secara online.

Komunitaas guru online berada dalam bingkai e-pembelajaran. Epembelajaran merupakan terjemahan dari istilah e-learning. Kementerian Pendidikan Nasional sudah menggunakan istilah epembelajaran, antara lain dalam rencana strategisnya (Depdiknas, 2010). Ada beberapa istilah lain yang umum digunakan untuk mengganti istilah e-pembelajaran, seperti pembelajaran berbasis komputer atau pembelajaran berbasis TIK. Ada pula pihak yang memaknai e-pembelajaran sebagai pembelajaran berbasis web karena materi pembelajaran didesain dalam wujud situs web dan ditempatkan di internet atau intranet. Huruf "e" dalam e-learning atau epembelajaran merupakan singkatan dari elektronic atau elektronik yang digunakan untuk menyebut semua teknologi yang digunakan untuk mendukung proses pembelajaran. Oleh karena itu pembelajaran yang memanfaatkan media internet, $C D$, DVD, flashdisk atau teknologi sejenis lainnya dikategorikan e-pembelajaran. Dalam penelitian ini, e-pembelajaran dimaknai sebagai pembelajaran yang memanfaatkan media internet. Materi pembelajaran disajikan dalam wujud web pembelajaran dinamik dan komunikasi pembelajaran dilakukan melalui surat elektronik (e-mail) dan chatting.

Web pembelajaran yang sering disebut modul berbasis web dikategoirikan sebagai model e-pembelajaran buatan guru karena memberi peluang kepada guru untuk mengembangkan sendiri bahan ajar dan menempatkannya pada portal. Bahan ajar yang dikembangkan guru menjadi kecenderungan e-pembelajaran saat ini karena bahan ajar yang dikembangkan guru lebih akurat dan lebih menarik daripada bahan ajar yang dikembangkan secara klinis oleh para ahli (Auvinen, 2009). Guru dan siswa tidak hanya menjadi pemakai epembelajaran, namun sekaligus sebagai pencipta dan pengembang bahan epembelajaran. Web pembelajaran dapat digunakan ulang (reusable), sehingga amat menguntungkan karena proses pembuatan desain pembelajaran pada beberapa bagian hanya terjadi sekali saja. Penggunaan ulang desain pembelajaran dapat diartikan sebagai penggunaan secara keseluruhan atau penggantian dokumen, baik lingkungan belajar, aktivitas, peran atau metode (Ragbir \& Mohan, 2009).

Agar mampu mengasimilasikan bahan ajar dalam e-pembelajaran, siswa mengembangkan serangkaian proses psikologis, seperti persepsi, perhatian, pemahaman, motivasi, memori, dan pikiran. Oleh karena itu, dalam e-pembelajaran perlu dikembangkan situasi belajar yang efektif dengan mengembangkan desain pembelajaran yang efektif mulai dari merumuskan tujuan pembelajaran sampai dengan menyusun assesmen pembelajaran untuk membantu kenyamanan belajar siswa. Sebagai desain pembelajaran digital, ada beberapa elemen disain yang harus dipenuhi oleh e-pembelajaran, baik disain visual maupun disain pedagogis, seperti pengaturan halaman, sistematika materi, ilustrasi, dan pewarnaan. Secara pedagogis, beberapa persyaratan yang harus dipenuhi dalam desain pembelajaran digital adalah sebagai berikut. 1) Secara simultan diikuti 
dengan pengembangankompetensi dan transmisi pengetahuan. 2) Mampu memfasilitasi struktur materi yang independen, baik untuk pembelajaran terstruktur maupun pembelejaran tidak terstruktur. 3) Mampu mengantisipasi perkembangan strategi berpikir yang efektif. 4) Mampu mengantisipasi tingkat perkembangan mental yang bervariasi (Istrate, 2009).

Kesinambungan materi dalam wujud teks, grafik, namimasi, atau video membantu terbentuknya koneksi antarkonsep untuk membentuk konsep baru. Dalam pembelajaran kontruktivis, kemampuan untuk membuat pengetahuan baru yang dapat diakses dan diperbaharui menjadi komponen yang amat penting. Selanjutnya,

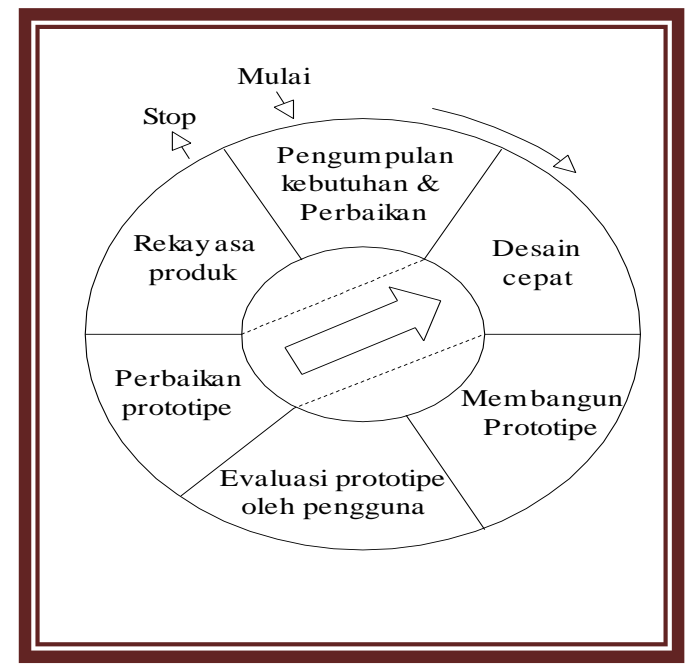

kemampuan untuk membuat sintesa dan membangun koneksi merupakan kemampuan yang amat diperlukan dalam zaman teknologi informasi. Proses belajar seperti itu disebut connect learning (Steiner \& Ehlers, 2010). Salah satu media yang efektif digunakan untuk memfasilitasi connect learning adalah web pembelajaran. Steiner \& Ehlers (2010) menjelaskan bahwa, connect learning berbasis konektivisme, konstruktivisme, dan pendekatan pembelajaran situasional lebih pada mengkonsolidasikan konsep yang dapat membantu memenuhi kebutuhan belajar pada skenario pembelajaran baru terorganisir, berorientasi pada pebelajar, komunikatif, serta bersifat sosial, emosional, dan situasional.

\section{METODE}

Penelitian ini secara keseluruhan direncanakan berlangsung dalam tiga tahun. Penelitian tahun pertama dilakukan pada tahun 2012, sedangkan penelitian tahun kedua direncanakan berlangsung pada tahun 2013, dan penelitian tahun ketiga direncanakan berlangsung tahun 2014. Penelitan tahun pertama merupakan penelitian rancang bangun, yakni pengembangan perangkat lunak portal web komunitas guru online. Efektivitas portal web tersebut dikaji melalui eksperimen pada penelitian tahun kedua. Portal web komunitas guru online yang dipandang efektif sebagai media pertukaran informasi pembelajaran disosialisasikan melalui penelitian tindakan kelas pada tahun ketiga. Penelitian pengembangan pada tahun pertama menggunakan model prototyping seperti tampak pada bagan di bawah ini.

pengumpulan data dan kebutuhan perangkat lunak lainnya. Setelah kebutuhan terkumpul dilanjutkan dengan perancangan desain cepat. Desain awal hasil desain cepat diimplementasikan untuk mendapatkan simulasi dari hasil akhir yang diinginkan dalam wujud prototype. Pada tahap evaluasi dilakukan evaluasi terhadap prototype yang sudah jadi. Jika hasil evaluasi belum sesuai dengan harapan, maka dilakukan revisi sampai diperoleh hasil yang diharapkan. Sebaliknya, jika hasil evaluasi sudah sesuai dengan harapan, maka dilakukan proses produksi.

Produk berupa perangkat lunak portal web komunitas guru online yang sudah dikembangkan kemudian diisi materi oleh administrator berupa video pembelajaran, animasi pembelajaran, media 
pembelajaran berupa gambar, serta beberapa dokumen pembelajaran berupa rencana pelaksanaan pembelajaran (RPP), paper atau modul. Selanjutnya, perangkat lunak tersebut diujicoba oleh para pakar perangkat lunak pembelajaran. Para pakar melakukan penilaian perangkat lunak dengan mengobservasi bagian internal program dan mencoba menjalankannya. Beberapa indikator yang dipertimbangkan adalah kebenaran operasional sistem, ketegaran sistem untuk mengantisipasi kondisi abnormal, kemampuan sistem beradaptasi bila terjadi perubahan spesifikasi, keterpakaian sebagian atau seluruh sistem untuk aplikasi lain, efisiensi sistem dalam pemanfaatan sumber daya, portabilitas program untuk ditransfer ke lingkungan perangkat keras yang berbeda, kemudahan verifikasi untuk menelusuri kegagalan program baik masih dalam validasi maupun setelah operasi, integritas sistem untuk untuk memproteksi diri dari penggunaan dan modifikasi illegal, kejelasan pengaturan modul-modul dalam perangkat lunak, dan keterbacaan perangkat lunak oleh orang lain selain programmer.

Rekomendasi para pakar dari hasil uji ditindaklanjuti dengan proses perbaikan atau revisi perangkat lunak. Perangkat lunak yang telah direvisi kemudian diujicobakan kepada guru dan siswa. Situs web komunitas guru online disosialisasikan kepada beberapa guru yang dijadikan sampel ujicoba, meliputi guru SD, guru SMP, dan guru SMA di sekitar Singaraja. Sampel diberi pelatihan mengisi materi untuk situs web komunitas guru online. Selain itu, para guru yang menjadi anggota sampel juga diberi pelatihan untuk melakukan komunikasi (diskusi) dan pertukaran informasi pembelajaran, khususnya informasi yang terunggah ke situs web. Di akhir proses ujicoba kepada para guru yang menjadi sampel dibagikan angket yang dilengkapi kolom untuk memberikan komentar. Indikator-indikator penilaian yang digunakan antara lain kinerja perangkat lunak, kemudahan pemakaian atau pengoperasian perangkat lunak, keramahan perangkat lunak untuk memberikan petunjuk kepada pengguna, kebergunaan atau kebermanfaatan perangkat lunak bagi pengguna, dan kemudahan proses pertukaran data.

Para guru yang menjadi sampel memberikan petunjuk kepada beberapa siswanya untuk mengakses sumber-sumber informasi pembelajaran yang ada di situs web komunitas guru online. Akhirnya, setelah jangka waktu yang memadai kepada para siswa yang terlibat dalam proses ujicoba diberikan angket yang juga dilengkapi kolom untuk memberikan komentar terbatas di sekitar pemanfaatan situs web komunitas guru online Indikatorindikator penilaian yang digunakan sama dengan indikator penilaian oleh guru yakni kinerja perangkat lunak, kemudahan pemakaian atau pengoperasian perangkat lunak, keramahan perangkat lunak untuk memberikan petunjuk kepada pengguna, kebergunaan atau kebermanfaatan perangkat lunak bagi pengguna, dan kemudahan proses pertukaran data. Hanya saja indikator-indikator tersebut dilihat dari sudut pandang siswa sebagai pengguna media. Respon yang diberikan siswa dianalisis secara kualitatif.

\section{HASIL DAN PEMBAHASAN}

Portal web komunitas guru on-line telah diimplementasikan. Beberapa layanan yang disediakan adalah pertukaran video, pertukaran gambar, pertukaran dokumen, dan media komunikasi untuk saling memebrikan komentar. Para guru yang menjadi anggota komunitas guru online dapat menempatkan rencana pelaksanaan pembelajaran (RPP), media pembelajaran, instrumen evaluasi, buku, modul, artikel, laporan penelitian, dan karya ilmiah lainnya yang dapat menunjang pelaksanaan pembelajaran. Para guru anggota komunitas secara bebas dapat saling mengakses 
sumber-sumber dan bahan-bahan pembelajaran tersebut. Para guru anggota komunitas benar-benar dapat bertukar informasi untuk saling melengkapi pengetahuan masing-masing. Situs web komunitas guru online juga dilengkapi fasilitas komunikasi yang lain, seperti e-mail dan short message systems (sms). Dengan demikian, situs web komunitas guru online dapat menjadi perpanjangan tangan MGMP (Musyawarah Guru Mata Pelajaran) untuk menjangkau guru-guru di lain daerah yang memiliki jarak geografis yang cukup jauh. Siswa dari berbagai daerah juga dapat secara bebas mengakses sumber-sumber dan bahan-bahan pembelajaran tersebut. Kondisi seperti ini diharapkan dapat menjamin pemerataan dan peningkatan mutu pendidikan.

Portal web komunitas guru online yang dikembangkan sudah diuji oleh pakar. Hasilnya menunjukkan bahwa portal web sudah memenuhi unsur kebenaran fungsi portal web sesuai spesifikasi yang ditentukan, yakni sebagai pembangun komunitas guru online. Ketegaran sistem untuk mengantisipasi kondisi abnormal juga sudah dipandang cukup sepanjang tidak terkait dengan koneksifitas. Kemampuan perangkat lunak untuk beradaptasi bila terjadi perubahan spesifikasi dinilai sudah cukup. Demikian pula keterpakaian sebagian atau seluruh sistem untuk aplikasi lain juga sudah mencukupi. Efisiensi sistem dalam pemanfaatan sumber daya memang dinilai masih perlu upaya, terutama bila informasi yang disajikan dalam bentuk video, anamiasi atau gambar. Portabilitas program untuk ditransfer ke lingkungan perangkat keras yang berbeda sudah didukung oleh fasilitas sistem operasi serta perangkat lunak pengembang yang digunakan. Verifikasi untuk menelusuri kegagalan program baik masih dalam validasi maupun setelah operasi dinilai cukup mudah dilakukan. Integritas perangkat lunak untuk memproteksi diri dari penggunaan dan modifikasi illegal dinyatakan masih perlu ditingkatkan. Kejelasan pengaturan modul-modul dalam perangkat lunak dinilai sudah memadai serta keterbacaan perangkat lunak oleh orang lain selain programmer juga dinilai sudah cukup. Beberapa masukan yang diberikan oleh para pakar antara lain: 1) portal perlu mempertimbangkan ukuran file, 2) portal perlu mempertimbangkan total media dari masing-masing anggota untuk dapat menetukan produktivitas anggota, dan 3) perlu ada mekanisme penjaminan kualitas media yang diunggah.

Selain uji pakar, portal web juga sudah diujicoba secara emperik dengan melibatkan beberapa orang guru. Hasil ujicoba menunjukkan bahwa kinerja portal web untuk bertindak sebagai media pertukaran informasi pembelajaran sudah cukup baik. Portal web cukup mudah untuk dioperasikan, sehingga tidak diperlukan keahlian khusus untuk mengoperasikannya. Petunjuk pemakaian portal web sudah dipandang cukup lengkap dan respon kepada pemakai juga sudah cukup lengkap, sehingga portal dipandang cukup ramah. Portal dinilai amat berguna dalam pertukaran informasi pembelajaran dan semakin banyak media yang terunggah semakin tinggi pula kebergunaan portal web. Proses pertukaran data atau informasi dinilai cukup mudah dilakukan. Hanya saja untuk pertukaran data masih menimbulkan pertanyaan dari beberapa guru karena dianggap rancu. Namun dengan penjelasan yang diberikan, para peserta menjadi memahami maksud pertukaran data dan bersedia mencoba. Beberapa masukan yang disampaikan para peserta guru antara lain: 1) perlu ada sistem pengamanan dari proses penjiplakan, 2) perlu ada regulasi pemanfaatan portal web, dan 3) perlu sosialisasi bertahap mulai pembuatan sampai pengunggahan media.

Hasil ujicoba terhadap sampel siswa yang dilakukan setelah ujicoba terhadap guru memberikan hasil yang tidak jauh berbeda dengan hasil ujicoba terhadap 
guru. Bahkan dalam bebrapa hal siswa cenderung lebih unggul ketimbang guru, seperti pada kemudahan pengoperasian dan kemudahan pertukaran data. Hal ini terjadi karena sesuai paradigma pemanfaatan teknologi, generasi muda jauh lebih cepat memahami teknologi daripada generasi tua. Hanya saja dalam hal kebergunaan atau kebermanfaatan mereka belum mampu memberi penilaian secara ideal. Penilaian mereka terbatas pada kepentingan pragmatis sesaat. Para siswa juga memberi masukan antara lain: 1) unsur keindahan perlu diperhatikan; 2) materi yang diajikan tidak terlalu formal, ada unsur permainan; dan 3) sajian dokumen perlu variasi tidak hanya file pdf.

Temuan di atas menujukkan bahwa portal web komunitas guru on-line dapat bertindak sebagai media yang memfasilitasi terjadinya subsidi silang informasi pembelajaran, baik antarguru, antarsiswa, maupun antara guru dan siswa. Karakteristik portal web yang mampu melewati batas waktu dan tempat diharapkan dapat membantu guru dan siswa untuk dapat mengakses materi pembelajaran dari sekolah lain, baik dalam satu wilayah maupun di luar wilayahnya. Guru dan siswa dari sekolah yang belum maju dapat mengakses informasi pembelajaran dari sekolah-sekolah lain yang sudah lebih maju. Guru dan siswa dari sekolah-sekolah yang sudah tergolong maju dapat saling bertukar informasi pembelajaran untuk saling memacu diri. Dengan demikian, guru dan siswa diharapkan dapat menciptakan komunitas on-line dalam belajar demi tercapainya peningkatan dan pemerataan mutu pendidikan. Komunitas guru on-line yang diutamakan adalah komunitas guru bidang studi, sehingga dapat menjadi perpanjangan tangan dari MGMP terbatas untuk memfasilitasi komunikasi guru mata pelajaran lintas kabupaten/kota dan lintas provinsi.

Komunitas guru on-line mampu menciptakan organisasi guru, utamanya guru mata pelajaran. Layanan utama yang diharapkan dari media ini adalah pertukaran informasi pembelajaran untuk peningkatan dan pemerataan mutu pendidikan. Layanan lain yang bisa diperoleh adalah publikasi karya ilmiah guru. Dengan demikian, karyakarya ilmiah guru yang sebetulnya sangat banyak dan banyak diantaranya sangat bermanfaat dapat dipublikasikan untuk dapat dimanfaatkan pihak lain yang memerlukan. Keuntungan yang tidak kalah pentingnya, melalui publikasi seperti ini hasil karya guru diharapkan dapat memperoleh pengakuan serta terlindungi dari tindakan kejahatan ilmiah. Dinas pendidikan dan LPMP dapat bekerjasama di bawah Kementerian Pendidikan dan Kebudayaan untuk mengelola media tersebut. Akibatnya, melalui media komunitas guru on-line karya ilmiah para guru dapat dinikmati pihak lain (baik sesama guru maupun bukan guru), terhindar dari kejahatan ilmiah, dan sekaligus memberi pendidikan kepada berbagai pihak untuk menghargai karya orang lain.

Portal web komunitas guru online menyajikan beberapa wujud pertukaran informasi antara lain informasi berupa video, informasi berupa gambar, dan informasi berupa teks. Kondisi ini dapat memperkaya variasi sumber belajar. Guru dapat memilih berbagai bentuk media untuk mendukung pembelajaran yang dilaksanakan. Apabila satu media dianggap belum memadai untuk memberikan informasi, maka guru dapat memilih media yang lain untuk mendukung. Di lain sisi, siswa juga dapat memilih media yang bervariasi untuk meningkatkan pemahaman materi. Apabila siswa merasa bingung menerima informasi dari satu media, maka siswa tersebut dapat memilih media yang lain atau bahkan media yang sama dari sumber yang berbeda. Selain itu, portal web komunitas guru online juga menyediakan media pertukaran informasi secara langsung untuk memberikan komentar, mengajukan pertanyaan, maupun memberikan tanggapan. Apabila guru perlu 
informasi pembelajaran tertentu, maka guru tersebut dapat menanyakan kepada guru lain. Sesuai kebiasaan yang berlaku di dunia maya (internet), guru lain yang memahami materi tersebut akan memberikan jawaban sesuai kapasitasnya. Hal yang sama juga akan terjadi antarsiswa serta antara siswa dan guru.

Portal web komunitas guru online telah diuji melalui beberapa pola pengujian, yakni uji kelayakan oleh pakar media berbasis teknologi informasi dan pakar pembelajaran, uji keterpakaian oleh para guru dan siswa, dan uji kebermanfaatan oleh pemerhati pembelajaran. Secara umum hasil uji coba adalah sebagai berikut. 1) Portal web komunitas guru online sudah cukup layak untuk digunakan sebagai media pertukaran informasi dalam wujud video, gambar, atau dokumen. Proses mengunggah video, gambar atau dokumen dapat dilakukan dengan mudah, tidak rumit dan tidak terlalu teknis, sehingga dapat dilakukan oleh semua guru dan tidak perlu dilakukan pelatihan khusus kepada mereka. 2) Portal web komunitas guru online sangat membantu guru dalam bertukar informasi pembelajaran. Guru-guru dari sekolah yang belum maju dapat mengunduh informasi pembelajaran dari guru-guru di sekolah yang lebih maju. Guru-guru dari sekolah yang tergolong maju dapat bertukar informasi pembelajaran dengan guru-guru dari sekolah-sekolah yang tergolong maju lainnya untuk saling melengkapi. Dengan demikian, portal web komunitas guru terbaik dapat memfasilitasi fertilisasi silang antarguru. 3) Portal web komunitas guru online memberi peluang kepada para guru untuk memperkenalkan hasil karya ilmiahnya kepada guru lain dan masyarakat umum. Selain meningkatkan kebermanfaatan karya ilmiah guru, pola ini juga membantu menghindarkan kegiatan plagiasi. 4) Portal web komunitas guru online membatu siswa untuk mendapatkan informasi pembelajaran, apalagi jika infomasi pembelajaran yang tersaji sudah bervariasi. Siswa yang ingin melakukan pengayaan atau belajar mendahului jadwal di sekolah akan terfasilitasi dengan baik oleh media ini. 5) Masyarakat umum, khususnya yang memahami masalah pendidikan sangat mendukung keberadaan media ini karena melalui media ini mereka dapat memberi masukan terkait materi pembelajaran atau kebijakan pendidikan. Kecenderungan siswa ke depan untuk semakin banyak bergaul di dunia teknologi informasi, sedikit atau banyak keberadaan media ini dapat menjadikan kegiatan siswa lebih terarah ke proses pembelajaran.

Saat sudah ada beberapa forum yang dapat memfasilitasi pertukaran informasi pembelajaran atau pendidikan secara umum, seperti MGMP dan K3S. Kemampuan forum-forum tersebut untuk menjangkau para guru terbatas oleh wilayah pemerintahan dan kondisi geografis. Indonesia merupakan negara kepulauan yang amat luas dengan kondisi geografis antardaerah yang sangat bervariasi. Variasi antardaerah juga terjadi pada besar penduduk, penyebaran penduduk serta pendapatan daerah maupun pendapatan penduduk, sehingga berimplikasi pada variasi capaian pembangunan, termasuk pembangunan pendidikan. Media berupa portal web komunitas guru online sangat membantu memperluas jangkauan forum komunikasi guru seperi MGMP maupun K3S. Karakteristik portal web yang bebas hambatan waktu dan jarak geografis mampu menjangkau guru dari berbagai daerah. Selain itu, jika forum seperti MGMP dan K3S lebih cenderung bekerja secara sinkronus, maka forum komunitas guru online cenderung bekerja secara asinkronus. Oleh karena itu, perbedaan waktu kerja guru tidak menjadi hambatan keterlibatan guru dalam komunitas guru online.

Lembaga pendidikan tenaga kependidikan (LPTK) yang bertugas mendidik calon guru sangat berkepentingan terhadap media seperti di atas. Produkproduk pembelajaran berupa rencana 
pelaksanaan pembelajaran (RPP), modul, buku ajar, media pembelajaran atau produk lainnya yang dibuat para guru dan dimuat pada situs komunitas guru online akan memberi pengalaman berharga kepada mahasiswa calon guru. Selain LPTK, lembaga penjamin mutu pendidikan (LPMP) juga sangat berkepentingan dengan media seperti itu. Pelatihan, workshop, atau kegiatan pembinaan guru yang lain yang diselenggarakan LPMP akan terlengkapi oleh media komunitas guru online. Dinas pendidikan yang bertanggungjawab dalam manajemen guru juga sangat terbantu dengan keberadaan media seperti komunitas guru online. Dinas pendidikan akan dapat memantau produktivitas guru, sekaligus memantau upaya-upaya peningkatan mutu pendidikan.

Hasil yang lebih optimal dalam pengelolaan media komunitas guru online dapat diraih apabila terjadi koordinasi yang baik antara tiga institusi yang paling dekat dengan pembinaan profesionalisme guru, yakni dinas pendidikan, LPMP, dan LPTK. Dinas pendidikan dapat bertindak selaku pengelola media komunitas guru online. Kewenangan dinas dalam manajemen guru memberi peluang kepada dinas pendidikan untuk menerbitkan regulasi keterlibatan guru dalam komunitas guru online. LPMP yang memiliki kewenangan menjamin kualitas guru bertanggungjawab terhadap pengkoordinasian operasional komunitas guru online. Wawasan dan kompetensi yang memadai dalam mengelola komunikasi antar-guru dalam berbagai aktivitas peningkatan kualitas guru akan sangat berguna untuk mengoganisasikan guru dalam komunitas guru online. LPTK yang memiliki peluang sangat luas untuk melakukan kajian akademis perencanaan dan pelaksanaan pembelajaran akan sangat baik bila dapat bertindak sebagai konsultan. Akan tetapi, pemilihan tugas seperti di atas tidak mutlak harus diikuti. Bagaimanapun juga kolaborasi ketiga lembaga tersebut akan memberikan hasil yang lebih optimal, khususnya bila menangani masalah-masalah riil di lapangan.

Tuntutan peningkatan mutu pendidikan dari masyarakat dan standarisasi mutu pendidikan yang ditunjukkan dengan adanya ujian nasional memacu sekolah untuk melakukan berbagai upaya untuk meningkatkan mutu layanan pembelajaran. Melihat kondisi tersebut, animo guru untuk tergabung ke dalam komunitas guru on-line akan tinggi, apalagi bila ditambah dengan adanya dorongan dari para kepala sekolah, komite sekolah, dan dinas pendidikan. Selain itu, kesinambungan portal web komunitas guru on-line akan dapat terpelihara dengan baik melalui koordinasi dengan lembagalembaga yang mengelola komunitas pelaksana pendidikan, seperti MGMP dan K3S). Apabila terjadi koordinasi yang baik di internal MGMP dan di internal K3S serta antara MGMP dan K3S, maka kesinambungan dan perkembangan komunitas guru on-line akan dapat dilakukan dengan lebih mudah.

\section{SIMPULAN DAN SARAN}

Portal web komunitas guru online sudah berhasil diimplementasikan dan sudah cukup layak untuk digunakan sebagai media pertukaran informasi dalam wujud video, gambar, atau dokumen. Proses mengunggah video, gambar atau dokumen dapat dilakukan dengan mudah, sehingga tidak perlu pelatihan khusus untuk para guru. Uji terbatas menunjukkan bahwa portal web komunitas guru online sangat membantu guru dalam bertukar informasi pembelajaran. Selain itu, portal web komunitas guru online memberi peluang kepada para guru untuk memperkenalkan hasil karya ilmiahnya kepada guru lain dan masyarakat umum, baik untuk meningkatkan kebermanfaatan maupun untuk membantu menghindarkan kegiatan plagiasi.

Portal web komunitas guru online membatu siswa untuk mendapatkan informasi pembelajaran, apalagi jika infomasi pembelajaran yang tersaji sudah 
bervariasi. Siswa yang ingin melakukan pengayaan atau belajar mendahului jadwal di sekolah akan terfasilitasi dengan baik oleh media ini. Masyarakat umum, khususnya para orang tua siswa amat mendukung keberadaan portal web komunitas guru online. Dengan memanfaatkan media ini, kegiatan siswa lebih terarah ke proses pembelajaran.

Komunitas guru on-line diharapkan menjadi organisasi guru, utamanya guru mata pelajaran. Layanan utama yang diharapkan dari media ini adalah pertukaran informasi pembelajaran untuk peningkatan dan pemerataan mutu pendidikan. Layanan lain yang bisa diperoleh adalah publikasi karya ilmiah guru. Dengan demikian, karyakarya ilmiah guru yang sebetulnya sangat banyak dapat dipubilkasikan untuk memperoleh pengakuan dan sekaligus dapat dimanfaatkan pihak lain, serta yang lebih penting dapat melindungi karya ilmiah para guru dari tindakan kejahatan ilmiah. Akibatnya, melalui media komunitas guru on-line karya ilmiah para guru dapat dinikmati pihak lain (baik sesama guru maupun bukan guru), terhindar dari kejahatan ilmiah, dan sekaligus memberi pendidikan kepada berbagai pihak untuk menghargai karya orang lain.

\section{DAFTAR PUSTAKA}

Auvinen, Ari-Matti, 2009, The Challenge of Peer Production eLearning Content, eLearning Papers, www.elearningpapers.eu, No 17, December 2009, ISSN 1887-1542
Depdiknas, 2010, Rencana Strategis Departemen Pendidikan Nasional 2010-2014, Jakarta: Depdiknas.go.id

Istrate, Olimpus, 2009, Visual and Pedagogical Design of eLearning Content, eLearning Papers, www.elearningpapers.eu, No 17, December 2009, ISSN 1887-1542

Ke, Fengfeng \& Christopher Hoadley, Evaluating Online Community Learning, Education Tech Research Dev (2009) 57:487-491 DOI 10.1007/s11423-009-9120-2.

Published online 28 February 2009 by Association for Educational Communications and Technology (2009).

Ragbir, Diana \& Permanand Mohan, Creating Reusable Lesson Plans for E-learning using the IMS Learning Design Specification, Education Journal of Education and Development Using ICT, Volume 5, Number 4, 2009, ISBN 1814-0556

Sofos, Alivisos \& Appostolos Kostas, 2009, Pedagogically-Oriented Evaluation Criteria for Web Resources, eLearning Papers, www.elearningpapers.eu, No 17, December 2009, ISSN 1887-1542

Steinert, Anne \& Ulf-Daniel Ehlers, 2010, ConnetLearning - an Answer for the New Challenges, eLearning Papers, www.elearningpapers.eu, No 18, Februari 2010, ISSN 1887-1542 